\begin{tabular}{ll}
\hline ISSN: 1410-8917 & Jurnal Kimia Sains dan Aplikasi 24 (3) (2021): 101-107 \\
Jurnal Kimia & Jurnal Kimia Sains dan Aplikasi \\
e-ISSN: 2597-9914 & Journal of Scientific and Applied Chemistry \\
\hline
\end{tabular}

\title{
Molecular Docking of Red Betel (Piper crocatum Ruiz \& Pav) Bioactive Compounds as HMG-CoA Reductase Inhibitor
}

\author{
Bella Fatima Dora Zaelani ${ }^{\mathrm{a},{ }^{*}}$, Mega Safithri ${ }^{a}$, Dimas Andrianto ${ }^{a}$ \\ ${ }^{\text {a }}$ Department of Biochemistry, Faculty of Mathematics and Natural Science, IPB University, Bogor, Indonesia \\ * Corresponding author: bellazaelani@apps.ipb.ac.id \\ https://doi.org/10.14710/jksa.24.3.101-107
}

\section{Article Info}

Article history:

Received: $19^{\text {th }}$ January 2021 Revised: $14^{\text {th }}$ March 2021

Accepted: $22^{\text {nd }}$ March 2021

Online: $31^{\text {st }}$ March 2021

Keywords:

bioactive compounds; HMG-

CoA reductase; molecular

docking; Piper crocatum

\begin{abstract}
Cholesterol plaque buildup in artery walls occurs due to oxidation of LowDensity Lipoprotein (LDL) molecules by free radicals, which are a risk factor for coronary heart disease. Piper crocatum contains active compounds that can act as HMG-CoA reductase inhibitors, such as flavonoids, alkaloids, polyphenols, tannins, and essential oils. This study aimed to predict the potential of Piper crocatum extract and fraction compounds as HMG-CoA reductase inhibitors by investigating the ligand affinity to the HMG-CoA reductase enzyme. Ligand and receptor preparation was conducted using BIOVIA Discovery Studio Visualizer v16.1.0.15350 and AutoDock Tools v.1.5.6. Molecular docking used AutoDock Vina, while ligand visualization and receptor binding used BIOAVIA Discovery Studio Visualizer vq6.1.0.15350 and PyMOL (TM) 1.7.4.5.Edu. The receptor used was HMG-CoA reductase (PDB code: $1 \mathrm{HWK}$ ) with atorvastatin as a control ligand. Catechin, schisandrin B, and CHEMBL216163 had the highest inhibition with affinity energies of $-7.9 \mathrm{kcal} / \mathrm{mol},-8.2 \mathrm{kcal} / \mathrm{mol},-8.3 \mathrm{kcal} / \mathrm{mol}$, respectively. Amino acid residues that played a role in ligand and receptor interactions were Ser684, Asp690, Lys691, Lys692.
\end{abstract}

\section{Introduction}

Hypercholesterolemia is a clinical symptom characterized by increased levels of total cholesterol $(\geq 220 \mathrm{mg} / \mathrm{dL}$ ) and low-density lipoprotein (LDL) cholesterol in the blood [1]. Hypercholesterolemia is a risk factor for cardiovascular disease, namely coronary heart disease (CHD). WHO data [2] showed that the number of deaths due to coronary heart disease was 8.9 million/year. Basic Health Research 2018 [3] showed the total prevalence of CHD and stroke in Indonesia was 1.5\% and $10.9 \%$, respectively. Significantly high intake of exogenous cholesterol increases cholesterol, triglyceride, and LDL levels. Coronary heart disease (CHD) is caused by an accumulation of cholesterol plaque on the walls of blood vessels, which causes the narrowing or blockage of blood vessels. The accumulation of cholesterol plaque in artery walls can occur due to the oxidation of LDL molecules by free radicals [4].

The enzyme 3-hydroxy-3-methyl-glutarylcoenzyme A (HMG-CoA) reductase is a key enzyme in cholesterol biosynthesis. This enzyme reduces HMGCoA to mevalonate, which is then converted into cholesterol [5]. On the other hand, red betel is known to have properties in treating various diseases, such as diabetes mellitus, cholesterol, gout, and hypertension [6]. Red betel contains flavonoids, alkaloids, polyphenols, tannins, and essential oils, which are useful as medicinal ingredients. Flavonoids have been reported to reduce LDL oxidation, suppress lipid peroxidation, and reduce atherosclerotic lesions' progression in cardiovascular disease [7].

Hasibuan et al. [8] conducted a study on the effect of giving red betel leaf extract. The results showed that the red betel leaf extract could maintain the levels of triglycerides, LDL, and normal total cholesterol in diabetic rats. Betel leaf methanol extract at a $256 \mathrm{mg} / \mathrm{kg}$ dose decreased total cholesterol by $42 \%$, LDL $26 \%$, and VLDL by $40 \%$ in mice [9]. Also, Rangkuti and Lubis [10] showed that red betel leaf nanoparticles at a dose of 100 $\mathrm{mg} / \mathrm{kg}$ BW on day 21 could reduce cholesterol levels in guinea pigs by $59.73 \%$. Based on these results, it is 
concluded that red betel can be a herbal alternative as an inhibitor of HMG-CoA reductase.

The discovery of drug design is a process that involves many disciplines, such as medicinal chemistry, pharmacy, and biochemistry, through an experimental approach. Many computational drug developments have been done to save costs and time, so the computational method to support drug design becomes more effective. Computational research on HMG-CoA reductase inhibition by herbal plants has been carried out from various plants, such as a water extract formulation of polyherbal [11], banana peel [12], and Azaricta indica [13]. However, computational research on the inhibition of the HMG-CoA reductase enzyme by red betel has not been carried out, so it is unknown how the interaction of active red betel compounds in inhibiting HMG-CoA reductase. This study aims to examine the potential of red betel extract and fraction compounds as HMG-CoA reductase inhibitors in silico by knowing the ligand affinity to the HMG-CoA reductase's active site enzyme.

\section{Methodology}

\subsection{Tools and materials}

This study was designed using a computer device with AMD A9-9420 Radeon R5, 5 Compute Cores 2C+3G processor specifications. The software used was MarvinView 6.0.0, BIOVIA Discovery Studio Visualizer v16.1.0.15350, AutoDock Tools v.1.5.6, AutoDock Vina, and PyMOL (TM) 1.7.4.5 Edu. The materials used were ligands of the extracted compound and the Piper crocatum fraction $[14,15,16,17,18]$ shown in Table 1.

\subsection{Prediction of Ligand Toxicity}

The prediction of ligand structure toxicity was carried out online using admetSAR by accessing the page http://lmmd.ecust.edu.cn/admetsar1/predict/. The ligand SMILES structure that would be predicted was uploaded to that page and then clicked on the predict option. The results of the prediction of toxicity appeared on that page [19].

\subsection{Molecular Docking Method Validation}

Method validation was conducted by determining the grid box using AutoDockTools v.1.5.6 and AutoDock Vina. The grid box dimensions were carried out at $x=18$, $\mathrm{y}=18, \mathrm{z}=18$ with a distance between the atoms of $1 \AA$. Molecular docking was validated until the root mean standard deviation (RMSD) was less than $2 \AA$ [20].

\subsection{Ligand and Receptor Preparation}

The ligands' three-dimensional structure was obtained from the Protein Data Bank (PDB) (pubchem.ncbi.nlm.nih.gov). The ligand structure was saved in sdf form and then converted into pdb format using MarvinView 6.0.0. The three-dimensional structure of the HMG-CoA reductase enzyme receptor (PDB code: $1 \mathrm{HWK}$ ) was taken from the Protein Data Bank (www.rcsb.org//pdb) in PDB format. The HMG-CoA reductase structure is a tetramer protein $(\mathrm{A}, \mathrm{B}, \mathrm{C}$, and D chains), the $A$ and $B$ chains used in docking. Ligand preparation was conducted by adding polar hydrogen atoms using Discovery Studio Visualizer v16.1.0.15350 and bond rotation using AutoDock Tools v.1.5.6. The receptor preparation used BIOVIA Discovery Studio Visualizer v16.1.0.15350 by eliminating water molecules, heteroatoms, and native ligands. The pdbqt protein file added polar hydrogen atoms and Gesteiger partial charges using AutoDock Tools v.1.5.6 [21].

Table 1. Compounds of red betel leaf extract

\begin{tabular}{|c|c|}
\hline Senyawa & PubChem ID \\
\hline Glabrescione & 44257338 \\
\hline Catechin & 73160 \\
\hline Caryophyllene & 5281515 \\
\hline Germacrene & 5317570 \\
\hline Elemicin & 10248 \\
\hline Propionic acid & 1032 \\
\hline Neophytadiene & 10446 \\
\hline Butyl ethanoate & 31272 \\
\hline Alfa pinene & 82227 \\
\hline Limonene & 22311 \\
\hline Cineole-1,8 & 2758 \\
\hline Terpinene-4-ol & 11230 \\
\hline 6X032ZSP1D & 75019 \\
\hline $\begin{array}{l}\text { Ethyl L-serinate hydrochloride } \\
\text { (1:1) }\end{array}$ & 2729185 \\
\hline Schisandrin B & 108130 \\
\hline Columbin & 188289 \\
\hline ZINC8756459 & 6070252 \\
\hline MLS000557666 & 1077234 \\
\hline Oprea1_462146 & 2865476 \\
\hline CHEMBL216163 & 44418672 \\
\hline $\begin{array}{l}\text { 1,1'-(1,4-Butanediyl)bis(2,6- } \\
\text { dimethyl-4-[(3-methyl-1,3- } \\
\text { benzothiazole-2(3H)-- } \\
\text { ylidene)methyl]pyridinium })\end{array}$ & 3414657 \\
\hline Methyl eugenol & 7127 \\
\hline 4-methoxyindole & 138363 \\
\hline $\begin{array}{l}\text { Leucylleucinamide hydrochloride } \\
(1: 1)\end{array}$ & 16219591 \\
\hline $\begin{array}{l}\text { 5-isopropyl-3- } \\
\text { pyrazolidinecarbohydrazide } \\
\text { hydrochloride (1:1) }\end{array}$ & 61440504 \\
\hline $\begin{array}{l}\text { 1H-pyrazole-1- } \\
\text { carboximidamidmidhydrochloride }\end{array}$ & 2734672 \\
\hline Protocatechuic acid & 72 \\
\hline $\begin{array}{l}\text { N1-(5-methylisoxazole-3- } \\
\text { yl)ethanediamide }\end{array}$ & 2805645 \\
\hline CHEMBL3217136 & 90665169 \\
\hline $\begin{array}{l}2-(4-\text { morpholinylmethyl)aniline } \\
\text { sulfate hydrate }\end{array}$ & 45595316 \\
\hline SCHEMBL569003 & 14839452 \\
\hline L-Arginine hydrochloride & 66250 \\
\hline $\begin{array}{l}\text { 1-(1,4-Dithian-2-ylmethyl)-3- } \\
\text { (3-methoxypropyl)thiourea }\end{array}$ & 116510220 \\
\hline ALBB-026042 & 1511955 \\
\hline
\end{tabular}




\subsection{Molecular Docking}

Molecular docking was conducted using AutoDock Vina. The prepared ligand and receptor structures were saved in .pdbqt format and copied to the Vina folder. Vina's AutoDock Program was run via Command Prompt (CMD). The programming command that was executed was "vina -config conf.txt -log log.txt." Molecular docking results obtained out documents in .pdbqt format and $\log$ in ' $t x t$ ' format containing ligand affinity energy [20].

\subsection{Visualization of ligand and receptor binding}

Two-dimensional visualization of hydrogen bonds and hydrophobic interactions of amino acid residues was carried out using BIOVIA Discovery Studio Visualizer v16.1.0.15350 [21] and three-dimensional using PyMOL $^{(\mathrm{TM})}$ 1.7.4.5 Edu [22].

\section{Results and Discussion}

\subsection{Prediction of Ligand Toxicity}

It is essential to identify the toxicity early in drug development. This is to ensure that the compound's potential as a drug can work effectively without causing damage to organs. Toxicity studies were carried out based on ADMET properties with the parameters taken, namely inhibition of hERG, carcinogenicity, and acute oral toxicity in rats. The hERG inhibition test results showed that the compound 2-(4-morpholinylmethyl) aniline sulfate hydrate was included in the strong inhibitor category for hERG. Meanwhile, control ligands and other test ligands are weak inhibitors of hERG. hERG is associated with $\mathrm{K}^{+}$channels in the normal repolarization of cardiac action. Blockage or other disruption of the $\mathrm{K}^{+}$channels in heart cells can cause cardiac arrhythmias and fatal cardiac toxicity [23].

Carcinogenicity prediction indicated that the test ligands belonging to group I (carcinogenic) include propionic acid, neophytadiene, and butyl ethanoate. While the control ligands and other test ligands were included in group 4 (non-carcinogenic), they are safe to be used as drugs. Acute toxicity in mice is based on the amount of the chemical administered orally in $\mathrm{mg} / \mathrm{kg}$ body weight resulting in mortality in $50 \%$ of the rat population. The prediction of acute oral toxicity indicates that the control ligands and all test ligands fall into category III ( $\mathrm{LD}_{50}<5000 \mathrm{mg} / \mathrm{kg}$ body weight), except for catechin ligands and L-(+)-arginine hydrochloride belongs to category IV $\left(\mathrm{LD}_{50}>5000 \mathrm{mg} / \mathrm{kg}\right.$ body weight) [24].

\subsection{Molecular Docking Validation}

Redocking complexed native ligands validated the molecular docking method into the HMG-CoA reductase crystal structure on the binding site. Molecular docking in this study was carried out on the active site of HMGCoA reductase, formed on the surface of two different subunits bound together to form dimers [25] (Figure 1b). In this case, molecular docking is carried out on the A and $B$ chains that make up the dimers. The active site residues of the enzymes targeted were Ser684, Asp690, Lys691, Lys692 [26]. The 1HWK structure contains one mutation. This did not affect the binding side of validation because mutations did not occur at the enzyme's residual active site [27]. Re-docking was conducted by comparing the native conformation of the ligands and the ligands from the redocking results. Assessment of validation is based on Root Mean Square Deviation (RMSD). The RMSD value shows the atomic distance's value at one conformation, with the nearest atom having the same type as the atom in another conformation [28].

Validation shows that the mean RMSD value is $0.9274 \pm 0.01 \AA$ with average affinity energy of $-9.3 \pm 0.1$ $\mathrm{kcal} / \mathrm{mol}$. The literal tethering method is considered accurate if the RMSD value for heavy atoms is $\leq 2.00 \AA$ [29]. These results indicate that the validated ligands and receptors have met the valid criteria, so the method can be used to determine the test compound. The visualization results show that the native hydrogen ligand interactions with the receptors are on the amino acids Ser565, Glu559, Arg590, Ser661, Ser684, Asp690, Lys691, Lys692, Lys735, Ala751, and Asn755. Meanwhile, the resulting hydrophobic interactions showed amino acid residues Cys561, Arg568, Leu562, Val683, His752, Leu853, Ala856, and Leu857. The redocking visualization is shown in Figure 1. (a)

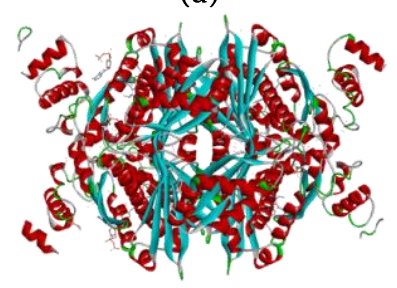

(c)

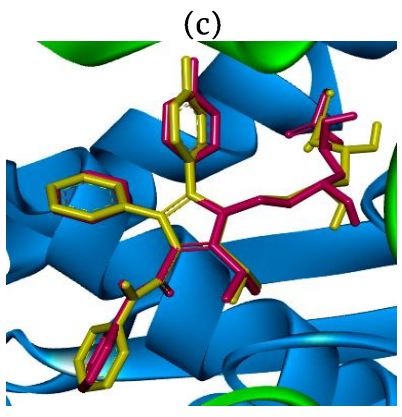

(b)

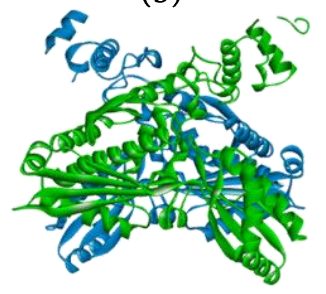

(d)

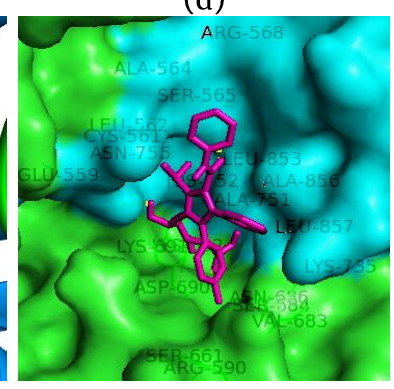

Figure 1. Visualization of the structure of (a) HMG-CoA reductase tetramer before preparation, (b) HMG-CoA reductase dimer consists of the $A$ chain (blue) and $B$ chain (green) after preparation, (c) overlap of native ligands (magenta) and ligands redocking results (yellow), (d) Binding pocket HMG CoA reductase

\subsection{Molecular Docking and Visualization}

From the molecular docking process, affinity energy was obtained as a direct output from AutoDock Vina. The increasingly negative affinity energy value indicated the highest inhibitory activity. The affinity energy values of all the compounds range from -3.6 to $-8.3 \mathrm{kcal} / \mathrm{mol}$, as shown in Table 2 . The highest affinity energy is found in the water extract, which is a catechin compound of 7.9 $\mathrm{kcal} / \mathrm{mol}$ with a Ki value of $1.60 \mu \mathrm{M}$, and the ethyl acetate fraction, which is a schisandrin $\mathrm{B}$ compound -8.2 $\mathrm{kcal} / \mathrm{mol}$ with a Ki value of $0.96 \mu \mathrm{M}$ and CHEMBL216163 of $8.3 \mathrm{kcal} / \mathrm{mol}$ with a value Ki of $0.81 \mu \mathrm{M}$. However, 
these results were still lower than that of atorvastatin which was $-9.5 \mathrm{kcal} / \mathrm{mol}$ with a $\mathrm{Ki}$ value of $0.13 \mu \mathrm{M}$. The inhibition constant value is calculated by using the equation $\Delta \mathrm{G}=\mathrm{RT} \ln \mathrm{K}_{\mathrm{i}}(\Delta \mathrm{G}=\mathrm{Gibbs}$ free energy (kcal $/ \mathrm{mol}), \mathrm{R}=1.986 \times 10^{-3} \mathrm{kcal} / \mathrm{mol} . \mathrm{K}, \mathrm{T}=298.15 \mathrm{~K}$ ) [30]. The inhibition constant is directly proportional to the affinity energy.

Table 2. Affinity Energy and amino acid residues of binding between ligands and receptors

\begin{tabular}{|c|c|c|c|c|c|c|}
\hline Ligand & 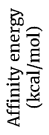 & $\mathrm{Ki}(\mu \mathrm{M})$ & 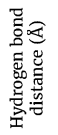 & $\begin{array}{l}\text { Hydrogen } \\
\text { bond }\end{array}$ & $\begin{array}{l}\text { Atoms } \\
\text { in } \\
\text { ligands }\end{array}$ & $\begin{array}{l}\text { Hydrophobic } \\
\text { interactions }\end{array}$ \\
\hline $\begin{array}{l}\text { Atorvastatin } \\
\text { (control) }\end{array}$ & -9.5 & 0.13 & $\begin{array}{l}2.88 \\
2.84 \\
2.94 \\
2.99 \\
3.02 \\
2.94 \\
3.02 \\
3.22 \\
3.03 \\
2.80 \\
2.80 \\
2.92 \\
3.25 \\
2.96\end{array}$ & $\begin{array}{l}\text { Ser565 } \\
\text { Glu559 } \\
\text { Arg590 } \\
\text { Ser661 } \\
\text { Ser684 } \\
\text { Asp690 } \\
\\
\text { Lys691 } \\
\text { Lys692 } \\
\text { Lys735 } \\
\text { Ala751 }\end{array}$ & $\begin{array}{c}018 \\
05 \\
\text { F1 } \\
\text { O1B } \\
\text { F1 } \\
01 B \\
03 \\
03 \\
03 \\
05 \\
\text { C1 } \\
01 A \\
01 A \\
03 \\
03 \\
05\end{array}$ & $\begin{array}{l}\text { Cys561, Arg568, } \\
\text { Leu562, Val683, } \\
\text { His752, Leeu853, } \\
\text { Ala856, Leu857 }\end{array}$ \\
\hline Glabrescione & -7.0 & 7.34 & $\begin{array}{l}2.89 \\
3.30\end{array}$ & Lys691 & $\begin{array}{l}\mathrm{O}_{3} \\
\mathrm{O}_{4}\end{array}$ & $\begin{array}{l}\text { Arg590, Glu559, } \\
\text { Met655, Met6657, } \\
\text { Asn658, Val683, } \\
\text { Ser684, Lys692, } \\
\text { Ala751, Asp767, } \\
\text { Leu853, Ala856, } \\
\text { Leu857, Gly860 }\end{array}$ \\
\hline Catechin & -7.9 & 1.60 & $\begin{array}{l}3.28 \\
3.17 \\
2.87 \\
2.72 \\
3.12 \\
2.87\end{array}$ & $\begin{array}{l}\text { Gly560 } \\
\text { Arg590 } \\
\text { Ser684 } \\
\text { Asp690 } \\
\text { Lys692 } \\
\text { Lys753 }\end{array}$ & $\begin{array}{l}\mathrm{O} 5 \\
\mathrm{O} 4 \\
\mathrm{O} 2 \\
\mathrm{O} 3 \\
\mathrm{O} 3 \\
\mathrm{O} 3 \\
\mathrm{O} 2\end{array}$ & $\begin{array}{c}\text { Glu559, Cys561, } \\
\text { Leu562, Ser565, } \\
\text { Ala751, His752, Leu853 }\end{array}$ \\
\hline Caryophyllene & -5.3 & 129.63 & - & - & - & $\begin{array}{l}\text { Arg590, Met657, } \\
\text { Ser68,, Asp690, } \\
\text { Lys691, Lys753, } \\
\text { Ala751, His752, } \\
\text { Asn755, Leu853, } \\
\text { Leu857 }\end{array}$ \\
\hline Germacrene & -5.5 & 92.48 & - & - & - & $\begin{array}{c}\text { Arg590, Met657, } \\
\text { Ser684, Asp690, } \\
\text { Lys692, Ala751, } \\
\text { His752, Leu853, } \\
\text { Leu857 }\end{array}$ \\
\hline Elemicin & -5.2 & 153.48 & 2.93 & Arg590 & 01 & $\begin{array}{c}\text { Ser684, Asp690, } \\
\text { Lys691, Lys692, } \\
\text { Ala751, His752, } \\
\text { Asn755, Leu853, } \\
\text { Leu857 }\end{array}$ \\
\hline Propionic acid & -3.6 & 2288.66 & $\begin{array}{l}2.81 \\
3.04 \\
3.03 \\
3.11 \\
3.12\end{array}$ & $\begin{array}{l}\text { Ser684 } \\
\text { Lys753 } \\
\text { Asp690 } \\
\text { Lys692 }\end{array}$ & $\begin{array}{l}\mathrm{O} 2 \\
\mathrm{O} 2 \\
\mathrm{O} 1 \\
\mathrm{O} 1 \\
02\end{array}$ & Ala751, Leu853 \\
\hline Neophytadiene & -4.9 & 254.74 & $\stackrel{3.12}{-}$ & - & $\begin{array}{l}02 \\
-\end{array}$ & $\begin{array}{c}\text { Glu559, Ser565, } \\
\text { Ars590, Ser684, } \\
\text { Asp690, Lys692, } \\
\text { Ala751, His752, } \\
\text { Asn755, Leu853, } \\
\text { Leu857 }\end{array}$ \\
\hline Butyl ethanoate & -4.1 & 983.68 & $\begin{array}{l}3.10 \\
2.95 \\
2.84 \\
3.22\end{array}$ & $\begin{array}{l}\text { Arg590 } \\
\text { Ser684 } \\
\text { Lys692 } \\
\text { Lys735 }\end{array}$ & $\begin{array}{l}\mathrm{O} 1 \\
\mathrm{O} 2 \\
\mathrm{O} 2 \\
\mathrm{O} 2\end{array}$ & $\begin{array}{l}\text { Glu559, Arg590, } \\
\text { Asp690, Lys691, } \\
\text { Asn755, Leu853, }\end{array}$ \\
\hline Alfa pinene & -4.0 & 1164.66 & 3.22 & Lys/35 & - & $\begin{array}{l}\text { Glu559, Arg590, } \\
\text { Asp690, Lys691, } \\
\text { Asn755, Leu853 }\end{array}$ \\
\hline Limonen & -4.9 & 254.74 & - & - & - & $\begin{array}{l}\text { Arg590, Ser684, } \\
\text { Asp690, Lys691, } \\
\text { Lys692, Ala751, } \\
\text { His752, Leu853, } \\
\text { Leu857 }\end{array}$ \\
\hline Cineole-1,8 & -4.4 & 592.68 & - & - & - & $\begin{array}{l}\text { Glu559, Gly560, } \\
\text { Cys561, Leu562, } \\
\text { His752, Leu853, } \\
\text { Leu857 }\end{array}$ \\
\hline Terpinen-4-ol & -5.3 & 129.63 & $\begin{array}{l}2.97 \\
3.08\end{array}$ & Arg590 & $\begin{array}{l}0 \\
0\end{array}$ & $\begin{array}{l}\text { Asp690, Lys691, } \\
\text { Lys692, Ala751, } \\
\text { His752, Asn755, } \\
\text { Leu853, Leu857 }\end{array}$ \\
\hline 6X032ZSP1D & -5.6 & 78.10 & $\begin{array}{l}2.87 \\
2.82 \\
2.88 \\
2.95 \\
2.95\end{array}$ & $\begin{array}{l}\text { Ser684 } \\
\text { Asp690 } \\
\text { Lys692 } \\
\\
\text { Lys735 }\end{array}$ & $\begin{array}{l}\mathrm{O} 2 \\
\mathrm{O} 2 \\
\mathrm{O} 2 \\
\mathrm{O} 1 \\
\mathrm{O} 2\end{array}$ & $\begin{array}{l}\text { Arg590, Ser661, } \\
\text { Val683, Ala751, } \\
\text { Leu853, Leu857 }\end{array}$ \\
\hline $\begin{array}{l}\text { Ethyl L-serinate } \\
\text { hydrochloride } \\
(1: 1)\end{array}$ & -4.7 & 357.09 & $\begin{array}{l}3.07 \\
3.11 \\
3.12 \\
2.76 \\
3.08 \\
2.89 \\
2.91 \\
3.25 \\
2.80\end{array}$ & $\begin{array}{l}\text { Arg590 } \\
\\
\text { Ser684 } \\
\text { Asn686 } \\
\text { Asp690 }\end{array}$ & $\begin{array}{l}01 \\
03 \\
03 \\
03 \\
02 \\
02 \\
\mathrm{~N} \\
\mathrm{O} 3 \\
\mathrm{~N} \\
\mathrm{O}\end{array}$ & $\begin{array}{l}\text { Lys691, Lys692, } \\
\text { Ala751, Leu853, } \\
\text { Leu857 }\end{array}$ \\
\hline Schisandrin B & -8.2 & 0.96 & $\begin{array}{l}3.00 \\
3.34 \\
2.80 \\
2.91 \\
2.78 \\
3.27 \\
3.00 \\
3.12\end{array}$ & $\begin{array}{l}\text { Glu559 } \\
\text { Ser684 } \\
\text { Lys691 } \\
\text { Lys692 } \\
\text { Lys735 } \\
\text { Ala751 } \\
\text { Asn755 }\end{array}$ & $\begin{array}{l}02 \\
05 \\
01 \\
04 \\
01 \\
01 \\
01 \\
01 \\
02 \\
02 \\
02\end{array}$ & $\begin{array}{l}\text { Ser565, Arg590, } \\
\text { Met655, Met657, } \\
\text { Asn658, Asp690, } \\
\text { His752, Leu853 }\end{array}$ \\
\hline
\end{tabular}

\begin{tabular}{|c|c|c|c|c|c|}
\hline Columbin & -6.3 & 23.94 & $\begin{array}{l}2.89 \\
3.00\end{array}$ & $\begin{array}{l}\text { Glu559 } \\
\text { Arg5590 }\end{array}$ & $\begin{array}{l}06 \\
03\end{array}$ \\
\hline ZINC8756459 & -6.7 & 12.18 & $\begin{array}{l}2.80 \\
2.81 \\
3.08 \\
2.95 \\
2.80 \\
3.10\end{array}$ & $\begin{array}{l}\text { Glu559 } \\
\text { Arg590 } \\
\text { Glu6655 } \\
\text { Lys692 } \\
\text { Lys735 } \\
\text { His752 }\end{array}$ & $\begin{array}{l}\text { N1 } \\
\text { O6 } \\
\text { N4 } \\
\text { O5 } \\
\text { O5 } \\
\text { O4 }\end{array}$ \\
\hline MLS000557666 & -6.9 & 8.69 & $\begin{array}{l}3.05 \\
3.14\end{array}$ & $\begin{array}{l}\text { Ser565 } \\
\text { Lys735 }\end{array}$ & $\begin{array}{c}\mathrm{N}_{4} \\
\mathrm{O}\end{array}$ \\
\hline Oprea1_462146 & -7.1 & 6.20 & 2.92 & Arg590 & $\mathrm{O} 2$ \\
\hline
\end{tabular}

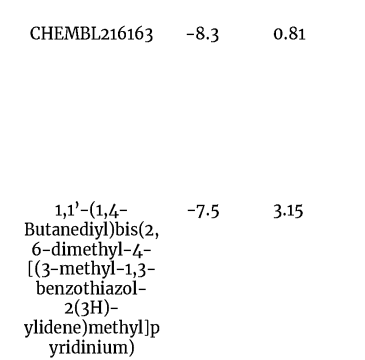

Methyl eugenol $\quad-5.3 \quad 129.63 \quad 2.99$

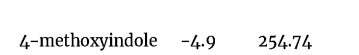

4-methoxyindole $\quad-4.9 \quad 254.74 \quad 3.22$
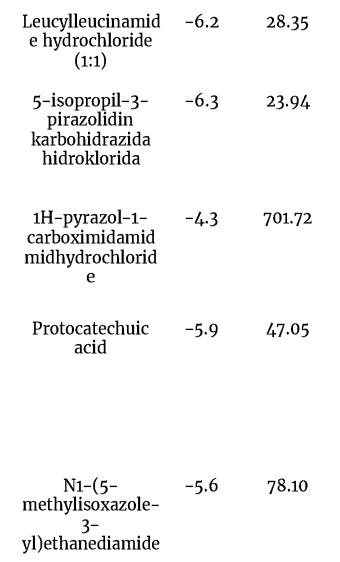

methylisoxazole-
$3-$
yl)ethanediamide

$\begin{array}{lll}\text { CHEMBL3217136 } & -5.9 & 47.05\end{array}$

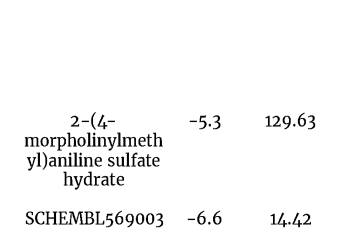

$\begin{array}{ll}2.83 & \text { Glu559 } \\ 3.00 & \text { Ser684 } \\ 2.70 & \text { Asp690 } \\ 3.00 & \text { Lys691 } \\ 2.98 & \text { Lys692 } \\ 3.04 & \text { Lys735 } \\ 2.70 & \text { Ala751 } \\ 3.09 & \text { Asn755 } \\ 2.95 & \text { Ser684 } \\ 2.78 & \text { Asp690 }\end{array}$

$\begin{array}{ll}2.85 & \text { Glu559 } \\ 3.11 & \\ 3.04 & \text { Arg590 } \\ 3.23 & \text { Asn755 } \\ 3.23 & \text { Arg590 } \\ 2.92 & \text { Ser684 } \\ 2.87 & \text { Asp690 } \\ 2.97 & \text { Lys692 } \\ 3.05 & \text { Lys735 } \\ 2.80 & \text { Ala751 }\end{array}$

$\begin{array}{lll}3.06 & \text { Glu559 } & \mathrm{N} \\ 2.80 & \text { Arg590 } & \text { O } \\ 3.12 & \text { Glu665 } & \text { N } \\ 2.85 & \text { Ans658 } & \text { N } 1 \\ 2.90 & \text { Ser684 } & \text { O } \\ 2.82 & \text { Asp690 } & \text { N } 11 \\ 3.03 & \text { Lys692 } & \text { N } 11 \\ 2.81 & \text { Lys735 } & \text { O } \\ 2.85 & \text { Ala751 } & \text { N } 11\end{array}$

$\mathrm{N} 3$
$\mathrm{O} 2$
$\mathrm{~N} 8$
$\mathrm{~N} 11$
$\mathrm{O} 2$
$\mathrm{~N} 1$
$\mathrm{~N} 11$
$\mathrm{O}$
$\mathrm{N} 11$

Ser661, Val683,

Ser684, Asp690,
Ala751, His752,

Leu857, Gly860

Gly560, Asn658,

Ser661, Val683,

(2)

Lys691, Ala751,

Leu857

Glu559, Arg590,

Ser684, Asp690,

(1)

Ala856, Leu857

Glu559, Gly560,

eus62, Ser 565 ,

Met657, Asn658,

Asp690, Lys692,

Lys735, Ala751,

Ala856, Leu857

Gly560, Ser661,
Cys688, Leu853 
Red betel compounds interact with the receptors via amino acid residues which form hydrogen and hydrophobic bonds. Visualization of ligand-binding amino acid residues with the receptor using BIOVIA Discovery Studio Visualizer v16.1.0.15350 and binding pocket HMG-CoA reductase using PyMOL PyMOL (TM) 1.7.4.5 Edu is shown in Figure 4. The visualization results showed that the three compounds, catechin, schisandrin, and CHEMBL216163, interact with Ser684, Asp690, Lys691, Lys692. This is consistent with Itsvan and Deisenhover [26], who stated that HMG-CoA reductase's binding pocket is present in amino acids 682-694, forming the cis loop, the active site of the enzyme. Based on this, the active compound of red betel is expected to act as a competitive inhibitor by binding to HMG-CoA reductase's active site.

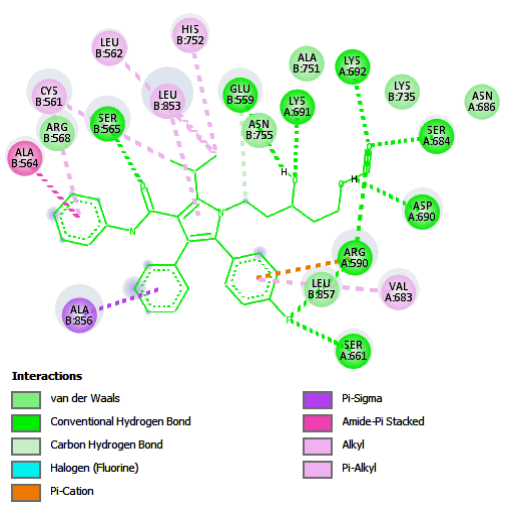

(a)

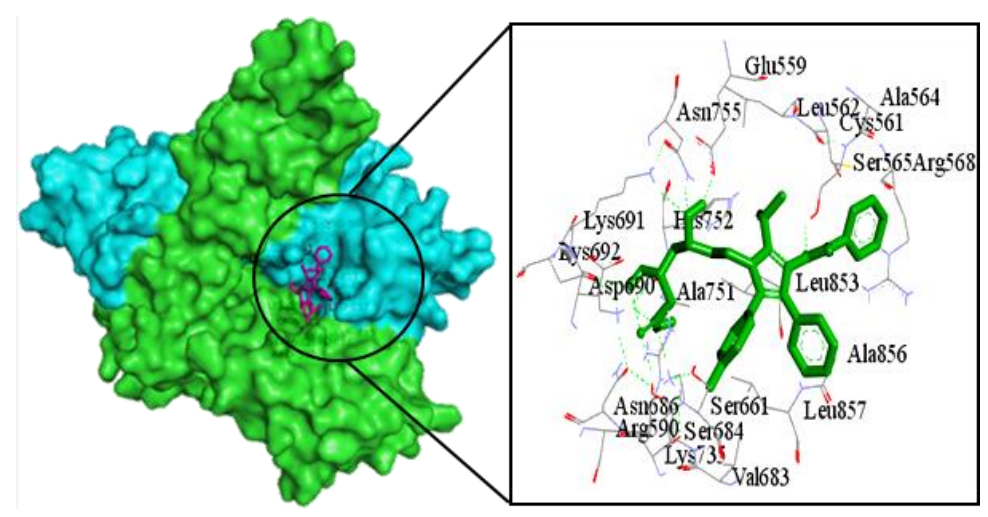

(b)

Figure 2. Molecular Docking Visualization of atorvastatin: A) 2D diagram of hydrogen bonding and hydrophobic interactions between ligands and receptors; B) Binding pocket of HMG-CoA reductase

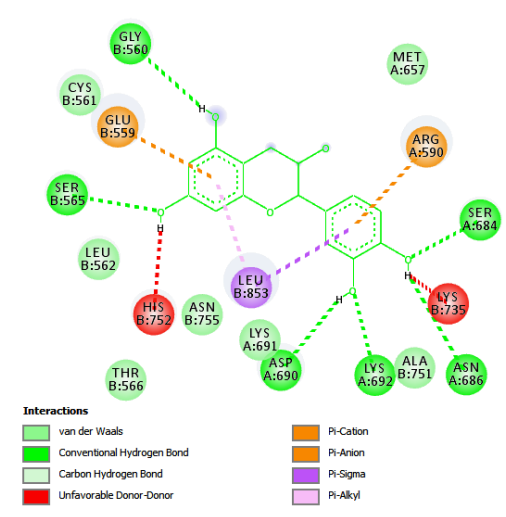

(a)

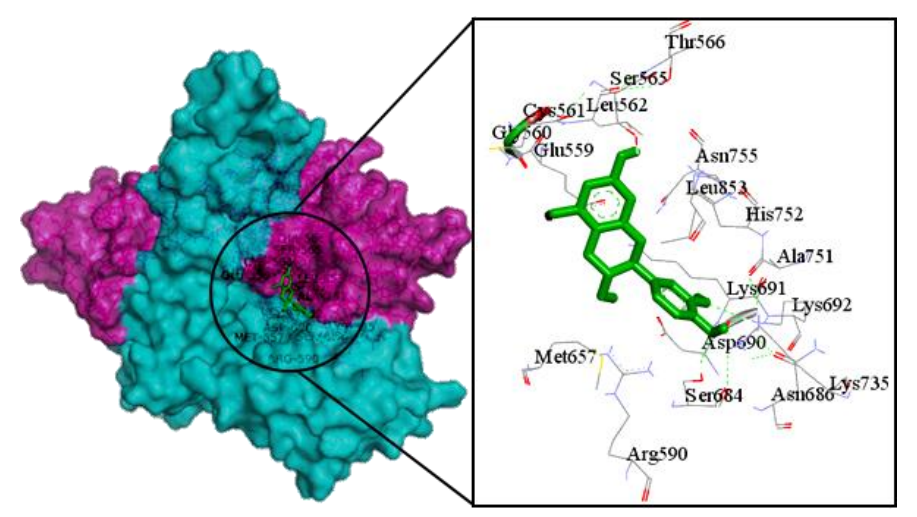

(b)

Figure 3. Visualization of Molecular Docking of catechins: A) 2D diagram of hydrogen bonding and hydrophobic interactions between ligands and receptors; B) 3D binding pocket structure of HMG-CoA reductase

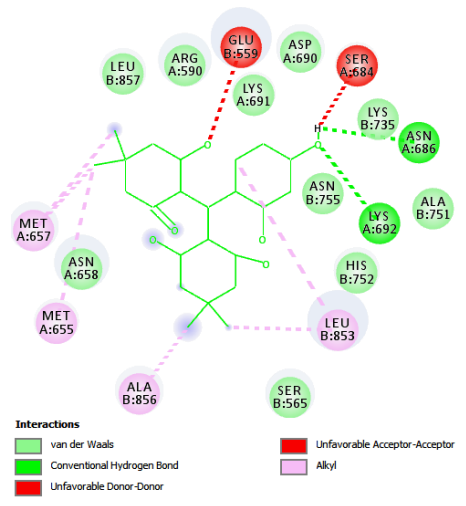

(a)

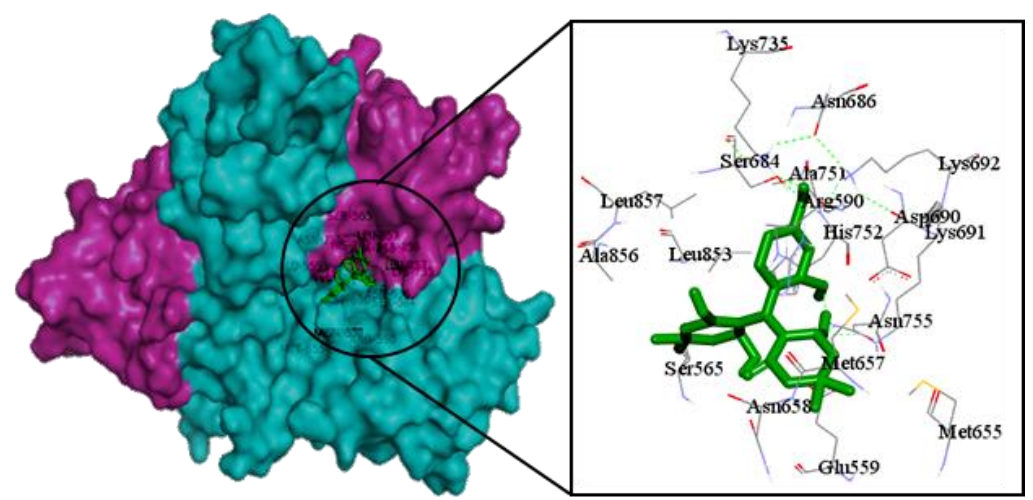

(b)

Figure 4. Visualization of the molecular docking of Schisandrin B: A) 2D diagram of hydrogen bonding and hydrophobic interactions between ligands and receptors; B) 3D binding pocket structure of HMG-CoA reductase 


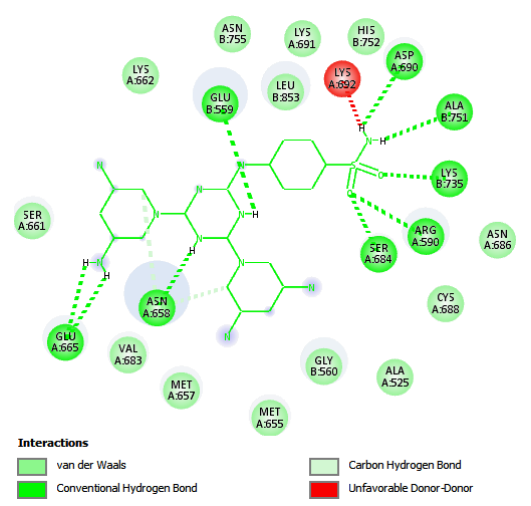

(a)

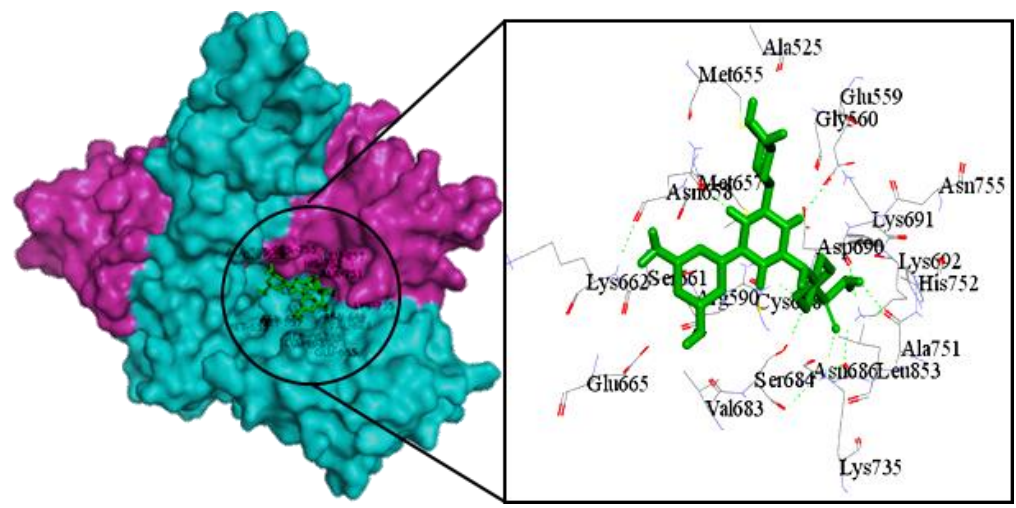

(b)

Figure 5. Visualization of the molecular docking of catechins: A) 2D diagram of hydrogen bonding and hydrophobic interactions between ligands and receptors; B) 3D binding pocket structure of HMG-CoA reductase

\section{Conclusion}

The computational interaction of red betel active compounds to predict ligands, which can inhibit the HMG-CoA reductase enzyme activity, is based on the energy affinity illustrated by the ideal ligand pose the active site of the enzyme. Red betel water extract compounds, namely catechins and ethyl acetate fraction; schisandrin and CHEMBL216163, have the highest energy affinity, namely $-7.9 \mathrm{kcal} / \mathrm{mol},-8.2 \mathrm{kcal} / \mathrm{mol}$, and $-8.3 \mathrm{kcal} / \mathrm{mol}$, respectively. They all interact with the active site of Ser684, Asp690, Lys691, and Lys692.

\section{References}

[1] P. McGowan Mary, Hamed Hosseini Dehkordi Seyed, M. Moriarty Patrick, P. Barton Duell, Diagnosis and Treatment of Heterozygous Familial Hypercholesterolemia, Journal of the American Heart Association, 8, 24, (2019), e013225 https://doi.org/10.1161/JAHA.119.013225

[2] World Heart Federation, Global Heart Special Issue The 2000-2016 WHF Global Atlas of CVD, World Heart Federation, 2018

[3] Badan Penelitian dan Pengembangan Kesehatan (LPB), Laporan Nasional Riskedas 2018, Badan Penelitian dan Pengembangan Kesehatan (LPB), Jakarta, 2018

[4] Jill Jin, Testing for "Silent" Coronary Heart Disease, JAMA, 312, 8, (2014), 858-858 https://doi.org/10.1001/jama.2014.9191

[5] Jonathan A. Tobert, Lovastatin and beyond: the history of the HMG-CoA reductase inhibitors, Nature Reviews Drug Discovery, 2, 7, (2003), 517-526 https://doi.org/10.1038/nrd1112

[6] Herryawan Herryawan, Indah Puti Rahmayani Sabirin, The effectiveness of red betel leaf (Piper crocatum) extract against periodontal pathogens, Bali Medical Journal, 7, 3, (2018), 732-735 http://doi.org/10.15562/bmj.v7i3.1173

[7] Gunasekaran Baskaran, Shamala Salvamani, Siti Aqlima Ahmad, Noor Azmi Shaharuddin, Parveen Devi Pattiram, Mohd Yunus Shukor, HMG-CoA reductase inhibitory activity and phytocomponent investigation of Basella alba leaf extract as a treatment for hypercholesterolemia, Drug design, development and therapy, 9, (2015), 509-517 https://doi.org/10.2147/DDDT.S75056
[8] Mega Safithri Hasibuan, Sedarnawati Yasni, Maria Bintang, Anna Setiadi Ranti, Antihyperglicemic activity of Piper crocotum leaves and cinnamomum burmanii bark mixture extract in streptozotocininduced diabetic rats, Journal of Mathematical and Fundamental Sciences, 48, 2, (2016), 178-191 https://doi.org/10.5614/j.math.fund.sci.2016.48.2.8

[9] Sonia Sharma, Adarsh Pal Vig, Evaluation of in vitro antioxidant properties of methanol and aqueous extracts of Parkinsonia aculeata L. leaves, The Scientific World Journal, 2013, (2013), Article ID 604865 https://doi.org/10.1155/2013/604865

[10] Saru Noliqo Rangkuti, Lely Sari Lubis, Uji Efektivitas Nanopartikel Daun Sirih Merah (Piper Crocatum Ruiz \& Pav.) sebagai Penurun Kadar Kolesterol Serum Darah Marmot (Cavia Cobaya), Jurnal Farmagazine, 5, 1, (2018), 31-39 http://dx.doi.org/10.47653/farm.v5i1.92

[11] J. Mercy Jasmine, R. Vanaja, In silico analysis of phytochemical compounds for optimizing the inhibitors of HMG CoA reductase, Journal of Applied Pharmaceutical Science, 3, 9, (2013), 43-47 http://doi.org/10.7324/JAPS.2013.3908

[12] Adelia Adrianne Tapiory, Kadita Octavia Pertiwi, Khalisa Fadilla, Davy Reyhanditya, Fatchiyah Fatchiyah, In-Silico Analysis of Methoxyl Pectin Compounds from Banana Peels as HMG-CoA Reductase Inhibitor Complexes, Journal of Smart Bioprospecting and Technology, 1, 2, (2020), 46-50 https://doi.org/10.21776/ub.jsmartech.2020.001.02.5

[13] Subramanian Suganya, Balaji Nandagopal, Anand Anbarasu, Natural Inhibitors of HMG-CoA Reductase-An Insilico Approach Through Molecular Docking and Simulation Studies, Journal of Cellular Biochemistry, 118, 1, (2017), 52-57 https://doi.org/10.1002/jcb.25608

[14] M Safithri, A Kurniawati, Formula of Piper crocatum, Cinnamomum burmanii, and Zingiber officinale extracts as a functional beverage for diabetics, International Food Research Journal, 23, 3, (2016), 1123-1130

[15] Mai Anugrahwati, Tuti Purwaningsih, Rustina, J. A. Manggalarini, N. B. Alnavis, D. N. Wulandari, H. D. Pranowo, Extraction of Ethanolic Extract of Red Betel Leaves and Its Cytotoxicity Test on HeLa Cells, Procedia Engineering, 148, (2016), 1402-1407 https://doi.org/10.1016/j.proeng.2016.06.569 
[16] Heni Sundari, M. Hatta Prabowo, Farida Juliantina Rachmawaty, Hady Anshory Tamhid, Standardization of leaf extract of red betel(Piper crocatum) leaves using ethanol, Jurnal Kedokteran dan Kesehatan Indonesia, 7, 1, (2016), 3-9 https://doi.org/10.20885/JKKI.Vol7.Iss1.art2

[17] Fitri Ramadani, Aktivitas antioksidan, total tanin ekstrak dan fraksi daun sirih merah (Piper crocatum) dan identifikasi dengan LC-MS, undergraduate thesis, Department of Biochemistry, IPB University, Bogor, 2018

[18] Ida Ayu Indah Wedaswari, Aktivitas Ekstrak Etanol dan Fraksi Daun Sirih Merah (Piper crocatum) dengan Metode Rancimat dan Identifikasi dengan LC-MS, undergraduate thesis, Department of Biochemistry, IPB University, Bogor, 2018

[19] Peter Juma Ochieng, Tony Sumaryada, Daniel Okun, Molecular Docking and Pharmacokinetic Prediction of Herbal Derivatives as Maltase-Glucoamylase Inhibitor, Asian Journal of Pharmaceutical and Clinical Research, 10, 9, (2017), 392-398 https://doi.org/10.22159/ajpcr.2017.v10i9.19337

[20] Oleg Trott, Arthur J. Olson, AutoDock Vina: Improving the speed and accuracy of docking with a new scoring function, efficient optimization, and multithreading, Journal of Computational Chemistry, 31, 2, (2010), 455-461 https://doi.org/10.1002/jcc.21334

[21] Garrett M. Morris, Ruth Huey, William Lindstrom, Michel F. Sanner, Richard K. Belew, David S. Goodsell, Arthur J. Olson, AutoDock4 and AutoDockTools4: Automated docking with selective receptor flexibility, Journal of Computational Chemistry, 30, 16, (2009), 2785-2791

https://doi.org/10.1002/jcc.21256

[22] Daniel Seeliger, Bert L. de Groot, Ligand docking and binding site analysis with PyMOL and Autodock/Vina, Journal of Computer-Aided Molecular Design, 24, 5, (2010), 417-422 https://doi.org/10.1007/s10822-010-9352-6

[23] Endang Lukitaningsih, Anny A. Mustikawaty, Ari Sudarmanto, Homology Modeling and Molecular Docking of Active Compounds from Bengkoang (Pachyrrhizus erosus) as Tyrosinase Inhibitor in Homo sapiens, Jurnal Ilmu Kefarmasian Indonesia, 11, 2, (2013), 134-141

[24] Xiao Li, Lei Chen, Feixiong Cheng, Zengrui Wu, Hanping Bian, Congying Xu, Weihua Li, Guixia Liu, Xu Shen, Yun Tang, In Silico Prediction of Chemical Acute Oral Toxicity Using Multi-Classification Methods, Journal of Chemical Information and Modeling, 54, 4, (2014), 1061-1069 https://doi.org/10.1021/ci5000467

[25] Diana S. Gesto, Carlos M. S. Pereira, Nuno M. F. S. Cerqueira, Sérgio F. Sousa, An Atomic-Level Perspective of HMG-CoA-Reductase: The Target Enzyme to Treat Hypercholesterolemia, Molecules, 25, 17, (2020), 3891 https://doi.org/10.3390/molecules25173891

[26] Eva S. Istvan, Johann Deisenhofer, Structural Mechanism for Statin Inhibition of HMG-CoA Reductase, Science, 292, 5519, (2001), 1160 https://doi.org/10.1126/science.1059344

[27] Eva S. Istvan, Johann Deisenhofer, The structure of the catalytic portion of human HMG-CoA reductase,
Biochimica et Biophysica Acta (BBA) - Molecular and Cell Biology of Lipids, 1529, 1, (2000), 9-18 https://doi.org/10.1016/S1388-1981(00)00134-7

[28] László Ferencz, Daniela Lucia Muntean, Possible substitutes for paracetamol: the results of a comprehensive screening based on structural similarity and docking simulation on the surface of enzymes, Farmacia, 63, (2015), 422-428

[29] Hari Purnomo, Kimia Komputasi untuk Farmasi dan Ilmu Terkait; Uji In Silico Senyawa Antikanker, Pustaka Pelajar, Yogyakarta, 2013

[30] Christopher Llynard D. Ortiz, Gladys C. Completo, Ruel C. Nacario, Ricky B. Nellas, Potential Inhibitors of Galactofuranosyltransferase 2 (GlfT2): Molecular Docking, 3D-QSAR, and In Silico ADMETox Studies, Scientific Reports, 9, 1, (2019), 17096 https://doi.org/10.1038/s41598-019-52764-8 